\title{
Ghrelin Stimulates Endothelial Cells Angiogenesis through Extracellular Regulated Protein Kinases (ERK) Signaling Pathway
}

\author{
Jun Wang ${ }^{1}$, Lin He ${ }^{2}$, Bahetiyaer Huwatibieke ${ }^{1}$, Lingchao Liu ${ }^{1}$, He Lan ${ }^{3}$, Jing Zhao ${ }^{1}$, \\ Yin $\mathrm{Li}^{1, *(1)}$ and Weizhen Zhang ${ }^{1}$ (D) \\ 1 Department of Physiology and Pathophysiology, School of Basic Medical Sciences, \\ Peking University Health Science Center, Key Laboratory of Molecular Cardiovascular Science, \\ Ministry of Education, Beijing 100191, China; wangjun_901016@sina.com (J.W.); tafcalgen@163.com (B.H.); \\ liulingchao@bjmu.edu.cn (L.L.); pujingle@163.com (J.Z.); weizhenzhang@bjmu.edu.cn (W.Z.) \\ 2 Department of Biochemistry and Molecular Biology, School of Basic Medical Sciences, \\ Peking University Health Science Center, Key Laboratory of Carcinogenesis and Translational Research \\ (Ministry of Education), Beijing 100191, China; helin910329@126.com \\ 3 Department of Clinical Laboratory, Capital Medical University, Beijing 100053, China; bylanhe08@126.com \\ * Correspondence: yinli@bjmu.edu.cn; Tel.: +86-10-8280-5613
}

Received: 18 May 2018; Accepted: 19 August 2018; Published: 26 August 2018

\begin{abstract}
Adipose tissue is hyper-vascularized. Vessels in adipose tissue not only supply nutrients and oxygen to nourish adipocytes, but also provide cytokines that regulate mass and function of adipose tissue. Understanding the fundamental mechanisms how vessels modulate adipocyte functions would provide new therapeutic options for treatment of metabolic disease and obesity. In recent years, researches about ghrelin are focused on glucose and lipid metabolism, but its effect on vascular function remains uncharacterized. In the present study, ghrelin receptor gene deletion mice (Ghsr ${ }^{-/}$mice) were used to study ghrelin-regulated vascular metabolism in white adipose tissue. Ghsr ${ }^{-/-}$mice demonstrated lower food intake, lower body weight, and resistance to high-fat diet-induced obesity. The number of vessels in white adipose tissue was decreased in Ghsr ${ }^{-1-}$ mice when compared with wild type mice fed with high-fat diet. To further define ghrelin effects in vitro, we used endothelial progenitor cells from wild type and $\mathrm{Ghsr}^{-/-}$mice as well as human umbilical vein endothelial cells in our experiments. We found that ghrelin stimulated endothelial cells angiogenesis and migration through the MEK-ERK signaling pathway. [D-Lys3]-GHRP-6 and PD98059 could reverse the effects of ghrelin on endothelial cells. Our study indicates that ghrelin activates its receptor on endothelial cells to promote angiogenesis and migration via a mechanism involving the extracellular regulated protein kinases (ERK) signaling pathway.
\end{abstract}

Keywords: ghrelin; endothelial cells; angiogenesis; migration; ERK

\section{Introduction}

Adipose tissues are highly vascularized, brown adipose tissue (BAT) is one of the most vascularized tissues in the body [1-3]. During adulthood, white adipose tissue (WAT) experiences an expansion or shrinkage depending on the energy consumption and metabolic demand of the host $[1,4]$.

Vascular system plays a significant role in controlling adipose tissue mass and functions [5-8]. It controls the fat mass by altering the number of capillaries. Angiogenic vessels not only supply nutrients and oxygen that are required for adipose tissue growth, but also provide growth factors and cytokines to maintain their physiological functions $[9,10]$. Alterations of WAT mass and functions coordinated with angiogenesis or vascular regression, which are regulated by various types of growth 
factors, cytokines, and adipokines [7]. Therefore, understanding the molecular mechanisms that control adipose tissue angiogenesis may provide new vascular targets for the treatment of obesity and metabolic disorders [11,12].

Ghrelin is a 28-AA peptide hormone that is secreted by X/A-like endocrine cells in the stomach [13]. Recent studies have found that ghrelin and its receptors are widely present in various organs and tissues [14]. Binding to its receptor- growth hormone secretagogue receptor 1a (GHSR1a), ghrelin plays a variety of biological effects, besides promoting the release of growth hormone, ghrelin also stimulates food intake and regulates fat metabolism [15]. As vasoactive peptide, ghrelin also has cardiovascular effects, such as lowering blood pressure, coronary artery expansion, improving heart failure, and a variety of other biological effects $[2,16,17]$.

In the present study, we found that except for lower body weight and resistance to high-fat diet-induced obesity, Ghsr ${ }^{-/-}$mice also had fewer vessels in adipose tissue when compared with wild type mice. In vitro experiments demonstrate that ghrelin stimulates angiogenesis and migration of endothelial cells by direct activating its receptor GHSR1a. This effect is mediated via the extracellular regulated protein kinases (ERK) signaling pathway. This study provides evidence that ghrelin plays a very important role in controlling endothelial angiogenesis and migration. In adipose tissue, lacking of ghrelin would decrease vascular density and thus result in smaller adipose tissue mass.

\section{Results}

\subsection{Effects of GHSR1a Blockade on Body Weight and Adipose Tissue Blood Vessels}

To determine whether the ghrelin receptor, GHSR1a, had effects on body weight and adipose tissue blood vessels, we used GHSR1a gene knockout mice (Ghsr ${ }^{-/-}$mice) to block the effects of endogenous ghrelin. Wild type mice fed with $45 \%$ high fat diet (HFD) for 12 weeks demonstrated significant increases in body weight relative to animals fed normal chow diet (NCD). As shown in Figure 1, Ghsr ${ }^{-/-}$mice were resistant to HFD-induced obesity, with body weight being significantly less than wild type littermates. We used the epididymal white adipose tissue isolated from wild type and $\mathrm{Ghsr}^{-/-}$mice fed with NCD or HFD for vWF immunohistochemistry, and found that $\mathrm{Ghsr}^{-/-}$mice had fewer blood vessels when compared with wild type mice that were fed with HFD (Figure 2A,B). For further investigation, we examined the vascular endothelial cell (EC) markers in epididymal adipose tissue of $\mathrm{Ghsr}^{-/-}$and wild type mice. Western blotting and qRT-PCR analysis showed that VEGF and CD31 expression were decreased in $\mathrm{Ghsr}^{-/-}$mice when compared with wild type littermates that were fed with HFD both in protein and mRNA levels (Figure 2C-E).
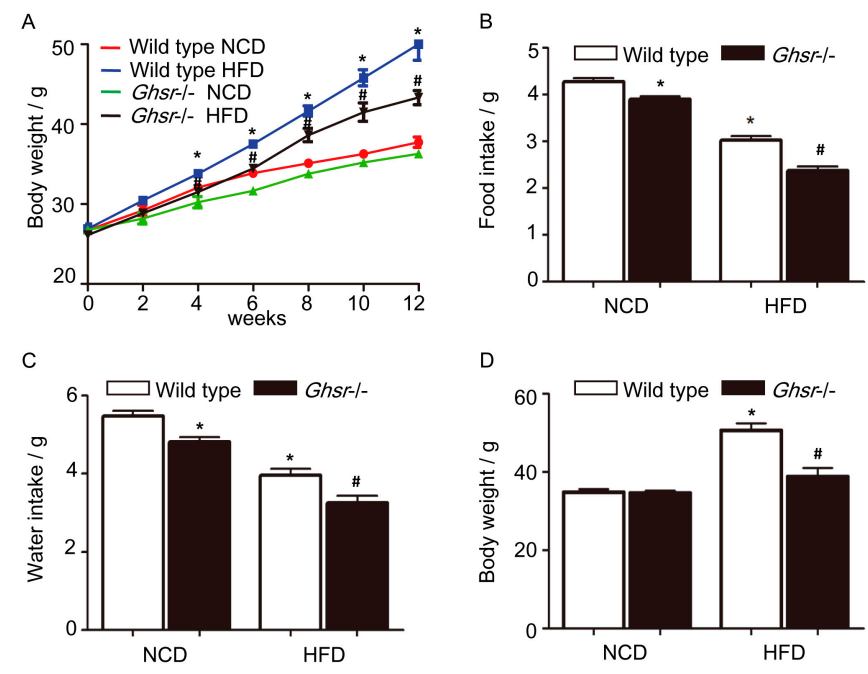

Figure 1. Cont. 
E

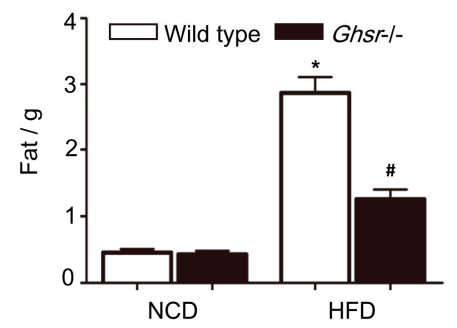

$\mathrm{F}$

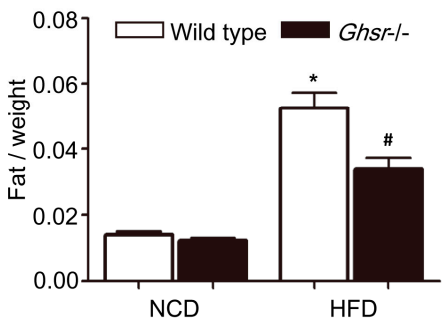

Figure 1. Phenotype of $\mathrm{Ghsr}^{-/-}$mice. Wild type or $\mathrm{Ghsr}^{-/-}$mice were fed with either normal chow diet (NCD) or $45 \%$ high fat diet (HFD) for 12 weeks. (A) Body weight change of wild type or Ghsr ${ }^{-/-}$ mice fed with NCD or HFD. (B-E) Average daily food intake (B), average daily water intake (C), average body weight (D) or average weight variation of epididymal adipose tissue (E) of wild type or $\mathrm{Ghsr}^{-/-}$mice fed with NCD or HFD is shown. (F) The epididymal adipose tissue/body weight ratio in wild type or Ghsr ${ }^{-/-}$mice fed with NCD or HFD is shown. Data are expressed as mean \pm SD, * denotes $p<0.05$ compared with wild type mice fed with NCD, ${ }^{*}$ denotes $p<0.05$ as compared with wild type mice fed with HFD.
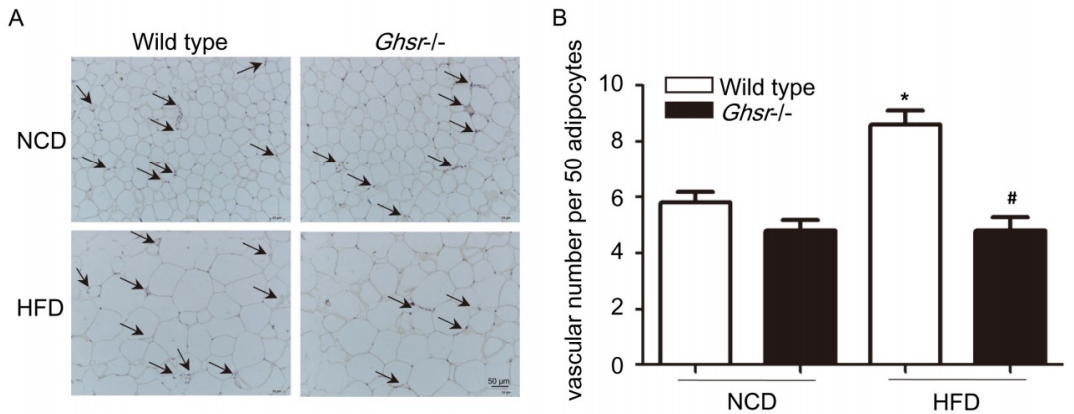

C

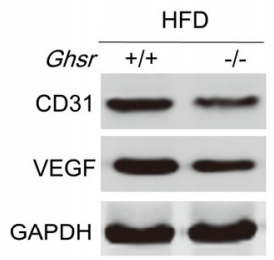

D
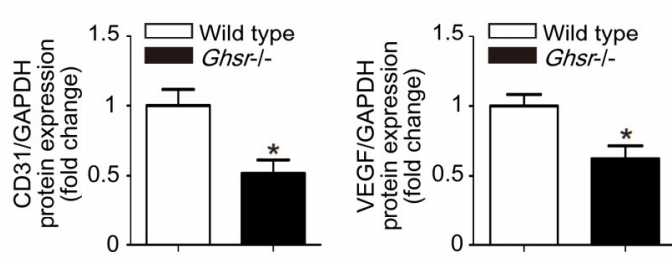

E
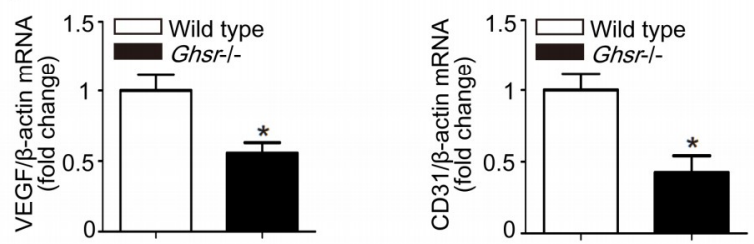

Figure 2. Blood vessels in adipose tissue of $\mathrm{Ghsr}^{-/-}$mice and wild type mice. Wild type or Ghsr1-/mice were fed with either NCD or 45\% HFD for 12 weeks. (A,B) Epididymal adipose tissues from wild type mice or $\mathrm{Ghsr}^{-/-}$mice were selected and stained with anti-vWF. Results are representative images from seven different animals. The arrows indicate positive staining. Microvessels are counted and averaged in 50 tissues sections. Magnification, $\times 100$. Data are expressed as mean $\pm \mathrm{SD}$, * denotes $p<0.05$ compared with wild type mice fed with NCD, ${ }^{*}$ denotes $p<0.05$ as compared with wild type mice fed with HFD. (C,D) The protein level of CD31, VEGF, or GAPDH was determined by western blotting analysis. (E) qRT-PCR analysis of the mRNA level of EC markers. Data are expressed as mean $\pm \mathrm{SD}, *$ denotes $p<0.05$. 


\subsection{Effects of Ghrelin Treatment on Angiogenesis and Migration In Vitro}

In the results above, we found that blood vessels were reduced in WAT of $\mathrm{Ghsr}^{-/-}$mice compared with wild type mice fed with HFD, suggesting that ghrelin plays a crucial role in angiogenesis. To determine whether ghrelin contributes to EC tube formation and migration, tube-forming ability assay and scratch-wound assay were performed.

Human umbilical vein endothelial cells (HUVECs) were treated with different concentrations of ghrelin and plated on Matrigel and cultured for $4 \mathrm{~h}$. As is shown in Figure 3A, tube formation increased significantly under ghrelin stimulating. Then, HUVECs were scratch-wounded and migrating cells were counted after $8 \mathrm{~h}$ under ghrelin treatment. As shown in Figure 3B, migration capability of HUVECs was also increased by ghrelin treatment.

A
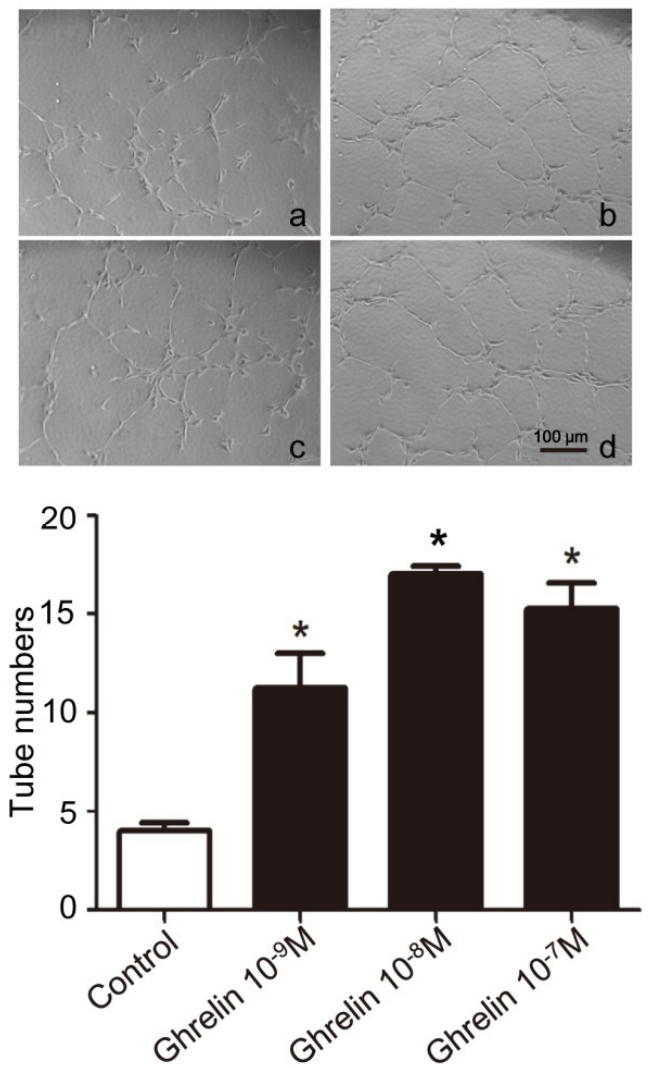

B
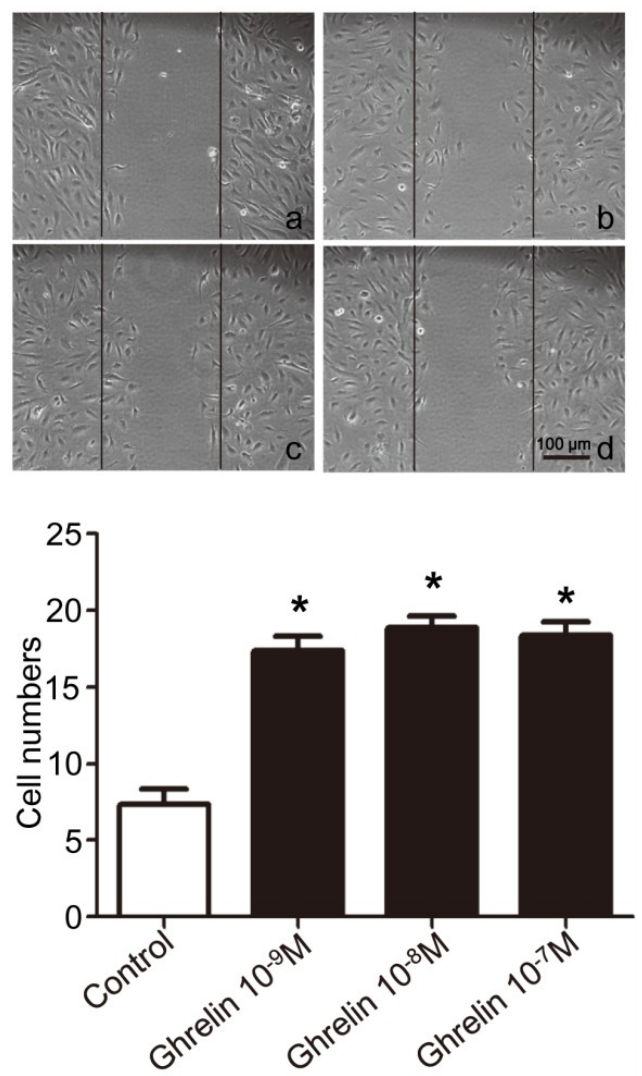

Figure 3. Cont. 
C
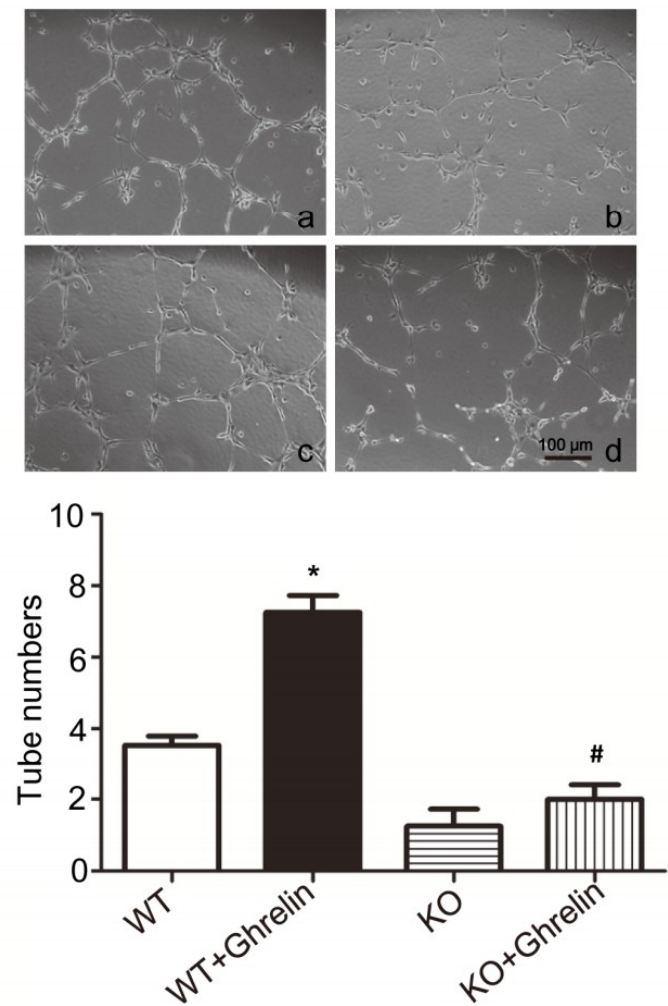

D
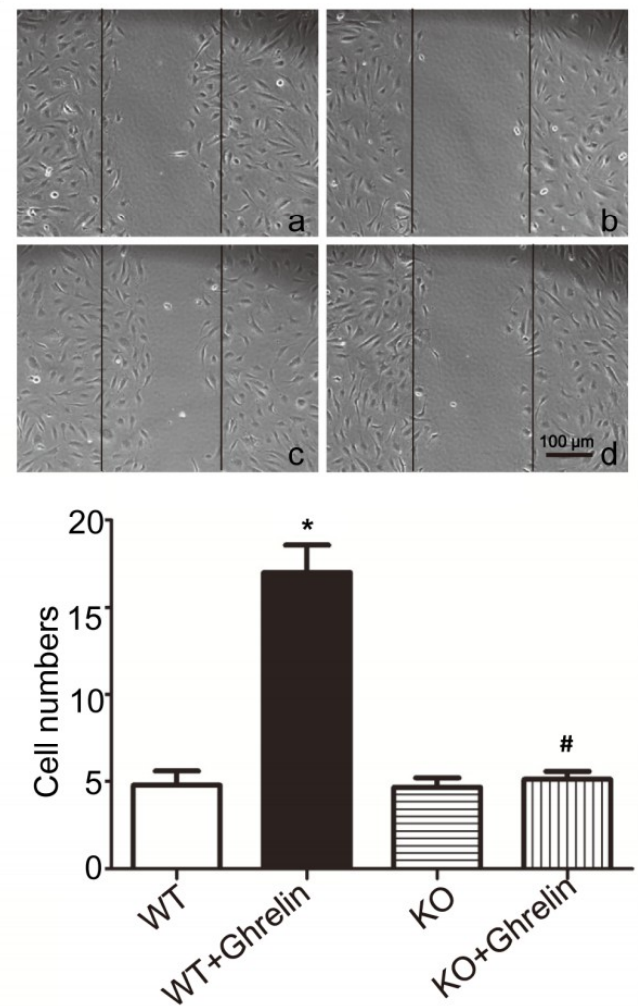

Figure 3. Ghrelin treatment stimulates tube formation and migration of human umbilical vein endothelial cells (HUVECs) and endothelial progenitor cells (EPCs) in vitro. (A) In vitro tube formation of HUVECs cultured on Matrigel with ghrelin treatment for $6 \mathrm{~h}\left(\mathrm{a}\right.$, control; $\mathrm{b}, 10^{-9} \mathrm{M}$ ghrelin; c, $10^{-8} \mathrm{M}$ ghrelin; $\mathrm{d}, 10^{-7} \mathrm{M}$ ghrelin). Magnification, $\times 100$. Tube-formation assay of HUVEC capillary morphogenesis after ghrelin treatment was shown. The extent of tube formation was determined by counting the tubes in five randomly chosen, low-power fields. (B) HUVECs were scratch-wounded and migrating cells were counted after $8 \mathrm{~h}$ with ghrelin treatment (a, control; b, $10^{-9} \mathrm{M}$ ghrelin; c, $10^{-8} \mathrm{M}$ ghrelin; $\mathrm{d}, 10^{-7} \mathrm{M}$ ghrelin), magnification, $\times 100$. Data are expressed as mean $\pm \mathrm{SD}$ from three independent experiments, each performed in triplicate $\left(^{*} p<0.05\right.$ compared with control group). (C) In vitro tube formation of EPCs cultured on Matrigel with ghrelin or N.S. treatment for $6 \mathrm{~h}$ (a, wild type EPCs + N.S.; b, Ghsr ${ }^{-1-}$ (KO) EPCs + N.S.; c, wild type EPCs $+10^{-8} \mathrm{M}$ ghrelin; $\mathrm{d}$, KO EPCs $+10^{-8} \mathrm{M}$ ghrelin), magnification, $\times 100$. Tube-formation assay of EPC capillary morphogenesis after ghrelin treatment was shown. The extent of tube formation was determined by counting the tubes in five randomly chosen, low-power fields. (D) EPCs were scratch-wounded and migrating cells were counted after $8 \mathrm{~h}$ with ghrelin or N.S. treatment (a, wild type EPCs; $b$, KO EPCs; $c$, wild type EPCs $+10^{-8} \mathrm{M}$ ghrelin; $\mathrm{d}$, KO EPCs $+10^{-8} \mathrm{M}$ ghrelin), magnification, $\times 100$. Data are expressed as mean $\pm \mathrm{SD}$ from three independent experiments, each performed in triplicate, ${ }^{*}$ denotes $p<0.05$ compared with EPCs from wild type mice without ghrelin administration, ${ }^{\#}$ denotes $p<0.05$ compared with EPCs from wild type mice with ghrelin administration.

To further examine the effects of ghrelin, we used endothelial progenitor cells (EPCs) that were isolated from $\mathrm{Ghsr}^{-/-}$and wild type mice. EPCs were cultured and identified by flow cytometry. EPCs were treated with $10^{-8} \mathrm{M}$ ghrelin and plated on Matrigel and cultured for $4 \mathrm{~h}$. EPCs were also scratch-wounded and migrating cells were counted after $8 \mathrm{~h}$ under ghrelin treatment. As shown in Figure $3 C, D$, tube formation and migration capability were increased by ghrelin in EPCs from wild type mice, but were not seen in EPCs from $\mathrm{Ghsr}^{-/-}$mice. 


\subsection{Effects of Ghrelin on the Phosphorylation of ERK in ECS}

As stated above, the effects of ghrelin were mediated by direct activation of its receptor, GHSR1a, and then activating intracellular signaling pathways to achieve $[13,18]$. Among the various signaling pathways, MEK-ERK pathway is involved in cell proliferation and differentiation, cell morphology and cytoskeleton maintain, and a variety of biological responses [19].

To determine whether ghrelin has effects on the phosphorylation of ERK in ECs, HUVECs were treated with different concentrations of ghrelin for $15 \mathrm{~min}$ or treated with $10^{-8} \mathrm{M}$ ghrelin for different time, followed by western blotting to determine the levels of phosphorylated ERK and total ERK. As shown in Figure 4A,B, ghrelin increases the phosphorylation of ERK on a time and concentration-dependent manner.

A
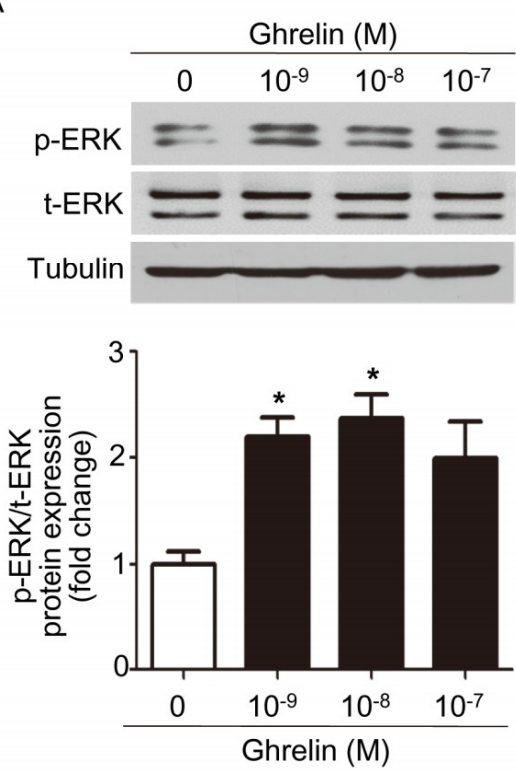

C

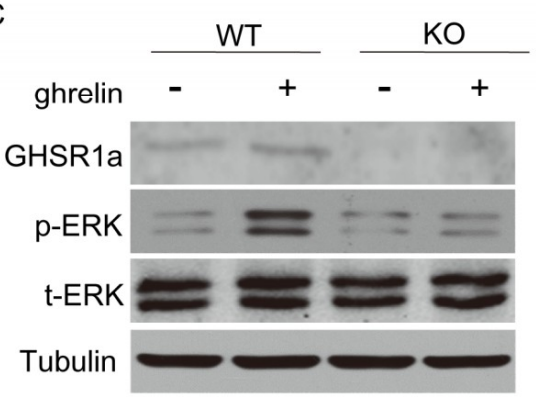

B
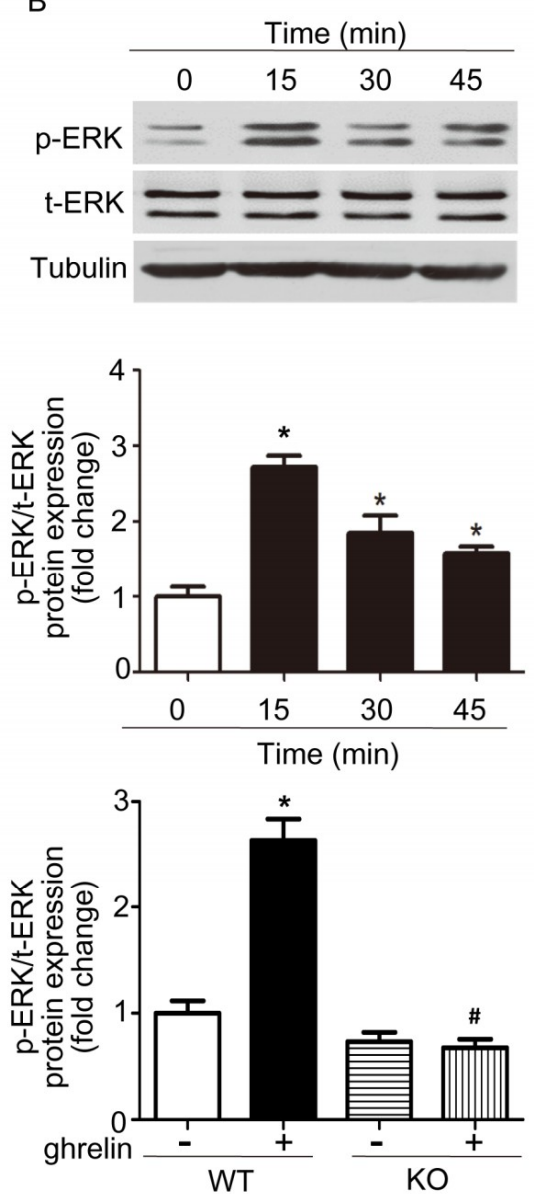

Figure 4. Ghrelin increases the phosphorylation of extracellular regulated protein kinases (ERK) in endothelial cells (ECs). (A) HUVECs were incubated with $10^{-9} \mathrm{M}, 10^{-8} \mathrm{M}, 10^{-7} \mathrm{M}$ ghrelin, or N.S. for $15 \mathrm{~min}$, and the level of phosphorylated ERK or total ERK was determined by western blotting analysis. (B) HUVECs were incubated with $10^{-8} \mathrm{M}$ ghrelin or N.S. for $0 \mathrm{~min}, 15 \mathrm{~min}, 30 \mathrm{~min}$, or $45 \mathrm{~min}$, and the level of phosphorylated ERK or total ERK was determined by western blotting analysis. Data are expressed as mean $\pm \mathrm{SD}$ from three independent experiments, each performed in triplicate ${ }^{*} p<0.05$ compared with control group). (C) EPCs from wild type and $\mathrm{Ghs}^{-/-}(\mathrm{KO})$ mice were incubated with $10^{-8} \mathrm{M}$ ghrelin or N.S. for $15 \mathrm{~min}$, and the level of phosphorylated or total ERK or GHSR1a was determined by western blotting analysis. Data are expressed as mean \pm SD from three independent experiments, each performed in triplicate, ${ }^{*}$ denotes $p<0.05$ compared with EPCs from wild type mice without ghrelin administration, ${ }^{\#}$ denotes $p<0.05$ compared with EPCs from wild type mice with ghrelin administration. 
We next analyze the effects of ghrelin on EPCs. EPCs isolated from $\mathrm{Ghs}^{-/-}$and wild type mice were incubated with $10^{-8} \mathrm{M}$ ghrelin for $15 \mathrm{~min}$, followed by western blotting to determine the levels of phosphorylated ERK and total ERK. We found that ghrelin increases the phosphorylation of ERK on EPCs from wild type mice, but has no effect on EPCs that were isolated from $\mathrm{Ghsr}^{-/-}$mice (Figure 4C). These results showed that the MEK-ERK pathway is involved in tube formation and migration of ghrelin on endothelial cells.

\subsection{Ghrelin Stimulates Tube Formation and Migration of EPCs through the ERK Dependent Manner}

The above experiments have verified that ghrelin stimulated phosphorylation of ERK in ECs, to intervene to gain further support of this proposition, EPCs that were isolated from wild type mice were treated with $10^{-8} \mathrm{M}$ ghrelin along with ghrelin receptor antagonist [D-Lys3]-GHRP-6 [20] or MEK-ERK inhibitor PD98059 [21]. As shown in Figure 5A, western blotting analysis showed that the antagonism of ghrelin function or inhibition of MEK-ERK pathway blocks the effect of ghrelin on ERK phosphorylation in EPCs. Furthermore, in vitro assays also showed that antagonism of ghrelin function or inhibition of MEK-ERK blocks the effect of ghrelin on tube formation (Figure 5B) and the migration of EPCs (Figure 5C).

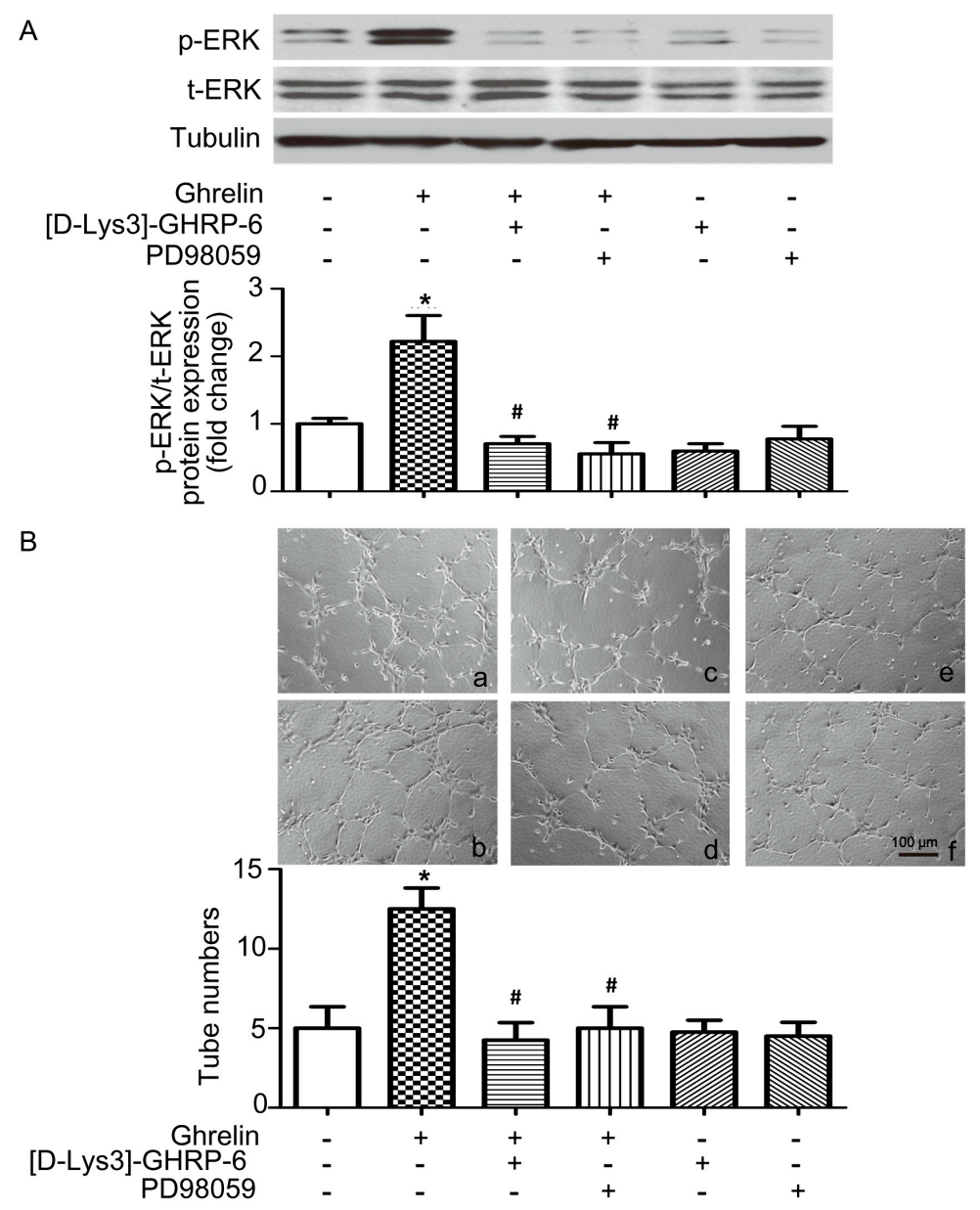

Figure 5. Cont. 


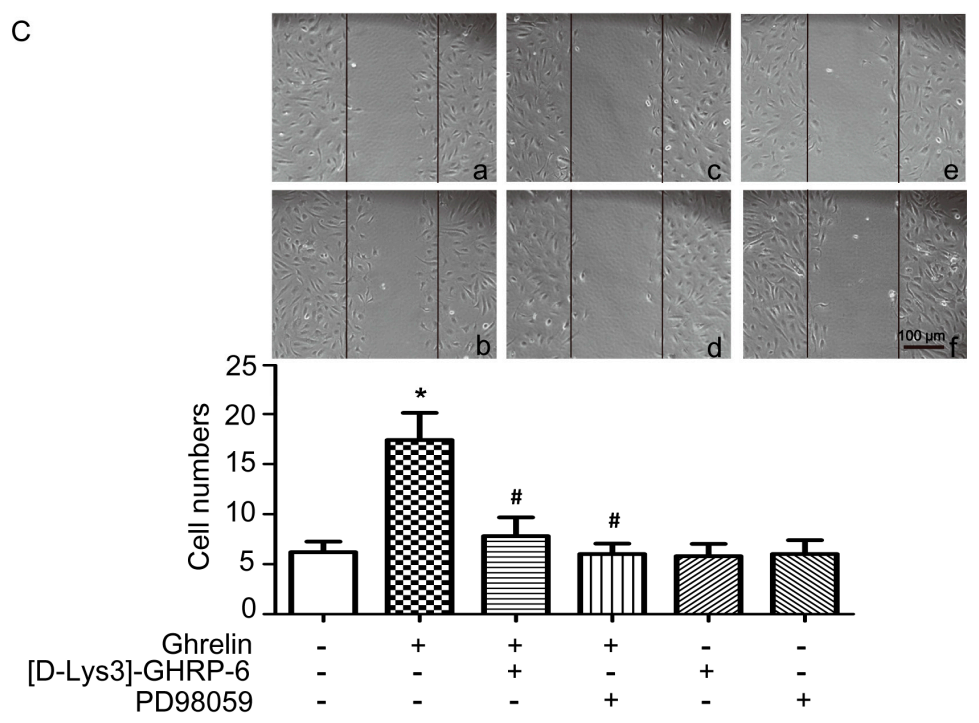

Figure 5. Ghrelin stimulates tube formation and migration of EPCs through the ERK dependent manner. (A) Wild type mice EPCs were pre-treated with $100 \mu \mathrm{M}$ [D-Lys3]-GHRP-6 or PD98059 for $30 \mathrm{~min}$, followed by incubating with $10^{-8} \mathrm{M}$ ghrelin or N.S. for $15 \mathrm{~min}$. The level of phosphorylated ERK or GAPDH was determined by western blotting analysis. (B) Tube-formation assay of EPC capillary morphogenesis after ghrelin treatment. In vitro tube formation of EPCs pre-treated with [D-Lys3]-GHRP-6 or PD98059 was performed by cultured on Matrigel with ghrelin or N.S. treatment and cultured for $6 \mathrm{~h}$, magnification, $\times 100$. The extent of tube formation was determined by counting the tubes in five randomly chosen, low-power fields. (C) EPCs pre-treated with [D-Lys3]-GHRP-6 or PD98059 were scratch-wounded and migrating cells were counted after $8 \mathrm{~h}$ with ghrelin or N.S. treatment, magnification, $\times 100$. a, EPCs + N.S.; b, EPCs $+10^{-8} \mathrm{M}$ ghrelin; c, EPCs $+10^{-8} \mathrm{M}$ ghrelin + $100 \mu \mathrm{M}$ [D-Lys3]-GHRP-6; d, EPCs + 10 ${ }^{-8}$ M ghrelin + $100 \mu \mathrm{M}$ PD98059; e, EPCs + $100 \mu \mathrm{M}$ [D-Lys3]-GHRP-6; f, EPCs + $100 \mu \mathrm{M}$ PD98059. Data are expressed as mean \pm SD from three independent experiments, each performed in triplicate, * denotes $p<0.05$ compared with EPCs without treatment, \# denotes $p<0.05$ compared with EPCs with ghrelin administration.

\section{Discussion}

Ghrelin and GHSR1a are widely present in various organs [14]. After binding together, ghrelin plays a variety of biological effects [22]. While multiple studies indicate that ghrelin plays an important role in controlling energy supply $[23,24]$, pathways mediating endothelial cells are less well-described.

In our previous study, we found that ghrelin plays important role in controlling glucose and lipid metabolism [23]. We also noticed that there was a change in adipose tissue blood vessels when intervened ghrelin and its receptor. White adipose tissues (WAT) and brown adipose tissues (BAT) are hyper vascularized. The vascular system plays a significant role in controlling adipose tissue mass and functions $[2,9,10,25,26]$. Understanding the fundamental mechanisms that vascular modulate adipocyte functions would provide new therapeutic options for the treatment of metabolic disease and obesity.

In order to intervene ghrelin and its receptor, we breed ghrelin receptor deletion mice (Ghsr ${ }^{-/-}$ mice) and wild type littermates mice as control. Fed with NCD or HFD for 12 weeks, we examined the vascular phenotype in epididymis adipose tissue. Immunohistochemistry, western blotting, and qRT-PCR assay are used to determine the vascular phenotype. After being fed with HFD, both immunohistochemistry, protein, and mRNA levels indicated that $\mathrm{Ghsr}^{-/-}$mice had fewer blood vessels.

Angiogenesis is the physiological process through which new blood vessels form from pre-existing vessels [27]. Angiogenesis is a normal and vital process in growth and development, which contains extracellular matrix degradation, endothelial cell activation proliferation, and migration, which is a 
complex process involving multiple molecules of a variety of cell $[9,28]$. Regression or overexpression of vessels will break the balance with adipose tissue metabolism [15,29].

Vascular functions in modulation of adipose tissue weight and insulin sensitivity are divided into two groups of views. One opinion is that the inhibition of vessels in adipose tissue leads to lean phenotype [2,30-33]. The other one is that acceleration of vessels would lead to lean phenotype in mice $[25,34,35]$.

The initial evidence of vasculatures in modulation of adipose metabolism was detected from $\mathrm{ob} / \mathrm{ob}$ and HFD induced obese mouse models that received treatment of an angiogenesis inhibitor, TNP-470, which is relatively specific for endothelial cells. TNP-470-treated obese mice had reduced vascular density of adipose along with smaller adipose tissue [2,33].

VEGF, which is an endothelial growth factor, plays a vital role controlling vessels in various organs. Temporal repression of systemic VEGF expression leads to a lean phenotype and resistance to diet-induced obesity [33]. On the other hand, several other studies show that overexpression, but not repression, of VEGF in adipose tissues protects against diet-induced obesity and insulin resistance $[25,34]$. Besides, in metabolic active adipose tissue (BAT), increase the blood vessels would lead to bigger energy consumption, which will inhibit the development of obesity $[36,37]$.

However, adipose tissue is one of the largest tissues in the body, the appropriate method of increasing or inhibiting angiogenesis therapy requires close coordination of the organizations and organs with consideration of their metabolic state $[6,25,31,33,34,38]$.

Ghrelin receptor deletion mice (Ghsr ${ }^{-/-}$mice) are resistant to high fat diet [23], have fewer adipose tissue mass [39], and fewer micro blood vessels in it. We detected whether ghrelin influences the process of angiogenesis directly or not. We chose different type of endothelial cells to examine the effects of ghrelin on angiogenesis. In our experiments, ghrelin is highly related to the tube formation and migration of the HUVECs and wild type mice EPCs, which is consistent with the previous reports with cardiac microvascular endothelial cells that were isolated from left ventricular myocardium of adult Sprague-Dawley (SD) rats [40]. When using the EPCs from wild type mice, ghrelin receptor antagonist, or MEK-ERK inhibitor significantly attenuated the effects of ghrelin on angiogenesis. The role of ghrelin receptor in the phosphorylation of ERK signaling pathway was further confirmed with $\mathrm{Ghsr}^{-/-}$mice, for ghrelin treatment could not activate ERK phosphorylation of EPCs from $\mathrm{Ghsr}^{-/-}$mice.

In conclusion, our studies suggest that ghrelin is a potent activator of angiogenesis. This finding may explain in part the lean phenotype observed in the $\mathrm{Ghsr}^{-/-}$mice fed with high fat diets.

\section{Materials and Methods}

\subsection{Ethical Approval}

The animals that were used in this study were handled in accordance with the Guide for the Care and Use of Laboratory Animals published by the US National Institutes of Health (NIH publication no. 85-23, revised 1996), and all of the experimental protocols were approved by the Animal Care and Use Committee of Peking University (Permit Number: LA2012-60, approved on 24 February 2012; and LA2016-123, approved on 24 February 2016). The investigators understand the ethical principles under which this journal operates and confirm that the work complies with the journal animal ethics checklist.

\subsection{Animals and Animal Care}

GHSR1a gene knockout mice (Ghsr ${ }^{-/-}$mice) in which exon 1 and exon 2 were deleted were obtained from the Shanghai Research Center for Biomodel Organisms [41]. Ghsr ${ }^{-/-}$mice and wild type mice were housed in standard plastic rodent cages and maintained in a regulated environment $\left(24{ }^{\circ} \mathrm{C}, 12 \mathrm{~h}\right.$ light and $12 \mathrm{~h}$ dark cycle with lights on at 0700 and off at 1900). Regular chow and water were available ad libitum unless specified otherwise. Where indicated, four-week-old mice were 
assigned to receive normal chow diet (control diet, D12450H; Research Diets) or a high fat diet ( $45 \%$ fat, D12451; Research Diets) for 12 weeks. Body weight was measured every week. Food and water intake was measured every three days and mean intake per day was calculated. Spillage was weighted and subtracted. Mice were then sacrificed and epidydimal fat pad were taken and weighed.

\subsection{Human Umbilical Vein Endothelial Cells (HUVECs) Culture, Identification, and Treatment}

The investigation confirmed to the principles outlined in the Declaration of Helsinki for use of human umbilical cord blood. The protocol was approved by Peking University Institutional Human Sample Use Committee. Briefly, human cord blood from umbilical cords of new born was collected with the use of heparin $(20 \mathrm{U} / \mathrm{mL})$ from donors with their written permission. Human cord blood HUVECs were isolated by density-gradient centrifugation with Ficoll $(1.077 \mathrm{~g} / \mathrm{mL})$ and plated on dishes that are coated with collagen type I ( $50 \mathrm{mg} / \mathrm{mL}$; Millipore, Burlington, MA, USA). M199 culture medium was supplemented with 20\% FBS, human VEGF $(10 \mathrm{ng} / \mathrm{mL})$, human bFGF $(1 \mathrm{ng} / \mathrm{mL})$, human EGF (10 ng/mL), IGF II (2 ng/mL), and LIF (10 ng/mL). HUVECs at passages 2-6 were used.

\subsection{Isolation and Identification of Mouse Bone-Marrow-Derived Endothelial Progenitor Cells}

Mouse bone-marrow-derived endothelial progenitor cell (EPC) isolation, culture, and identification were as previously described [42]. Briefly, EPCs were collected by flushing the femurs and tibias of wild-type or $\mathrm{Ghsr}^{-/-}$mice, 8-10 weeks old, with EGM-2 medium containing $10 \%$ FBS. Cells were plated on type I collagen-coated dishes and maintained in a humidified atmosphere containing $5 \% \mathrm{CO}_{2}$ at $37^{\circ} \mathrm{C}$. After $4-7$ days in culture, non-adherent cells were removed and adherent cells were cultured for an additional 10 days and then used for further analysis. This population grew at a high proliferation rate into a monolayer of spindle-shaped cells. EPCs at passages 2-4 were used in the following experiments. EPCs were identified as exhibiting high levels of endothelial lineage markers UEA, c-kit and CD31. Moreover, we identified their tube-forming function by their pro-angiogenic capacity to form tube-like structures on Matrigel [43].

\subsection{Protein Extraction and Western Blotting}

Western blot analysis was carried out according to standard protocols. Cultured cells were harvested and homogenized in ice-cold fractionation buffer containing RIPA lysis buffer, Phenylmethanesulfonyl fluoride (PMSF), and protein phosphatase inhibitor mixture. The cell lysate was treated with ultrasound for $3 \mathrm{~s}$ three times, and then centrifuged at 12,000 rpm for $10 \mathrm{~min}$ at $4{ }^{\circ} \mathrm{C}$. After centrifugation, the supernatant was used for Western blot analysis. Protein concentration was measured by the Bradford's method. A total of $40 \sim 60 \mu \mathrm{g}$ protein from each sample was loaded. Proteins were transferred to polyvinylidene fluoride membranes. The membranes were incubated for $1 \mathrm{~h}$ at room temperature with $4 \%$ fat-free milk in Tris buffered saline containing Tween-20, followed by incubation overnight at $4{ }^{\circ} \mathrm{C}$ with the individual primary antibody. Specific reaction was detected using IRDye conjugated second antibody and visualized while using the Odyssey infrared imaging system (LI-COR Biosciences, Lincoln, NE, USA). Quantification of image density in pixel was performed using the Odyssey infrared imaging system (LI-COR Biosciences, Lincoln, NE, USA). Primary antibodies used were anti-p-ERK, and anti-ERK (1:1000; Cell Signaling, Beverly, MA, USA); anti-vWF, anti-GHSR1a, and anti-VEGF (1:1000; Santa Cruz Biotech nology, Santa Cruz, CA, USA); and, anti-GAPDH and anti- $\beta$-actin (1:1000; Abcam, Cambridge, MA, USA).

\subsection{Quantitative Real-Time Polymerase Chain Reaction ( $q R T-P C R$ )}

Total RNA was isolated while using the TRIzol reagent (Invitrogen, Carlsbad, CA, USA). Reverse transcription was performed using the RT system according to the manufacturer's instruction. PCR was conducted in a $25 \mu \mathrm{L}$ volume containing $2.5 \mu \mathrm{L}$ cDNA, $5 \mathrm{mM} \mathrm{MgCl}_{2}, 0.2 \mathrm{mM}$ dNTPs, $0.2 \mu \mathrm{M}$ each primer, $1.25 \mathrm{U}$ AmpliTaq Polymerase, and $1 \mu \mathrm{L} 800 \times$ diluted SYBRGreen I stock while using the Mx3000 multiple quantitative PCR system (Strata gene, La Jolla, CA, USA). PCR reactions were 
performed in duplicate. Primers used in this study are shown in Table 1. All the mRNA expression was quantified using the comparative cross threshold $(\mathrm{Ct})$ method. The $\mathrm{Ct}$ value of the housekeeping gene $\beta$-actin was subtracted from the $C t$ value of the target gene to obtain $\Delta C t$. The normalized fold changes of target gene mRNA expression were expressed as $2^{-\Delta \Delta C t}$, where $\Delta \Delta C$ t equals to $\Delta C$ t sample $-\Delta C \mathrm{t}$ control.

Table 1. List and sequence of primers.

\begin{tabular}{ccc}
\hline & Upstream Primer $\left(5^{\prime} \mathbf{- 3}^{\prime}\right)$ & Downstream Primer $\left(\mathbf{5}^{\prime} \mathbf{- 3}^{\prime} \mathbf{)}\right.$ \\
\hline GHSR1a & CTATCCAGCATGGCCTTCTC & AAGACGCTCGACACCCATAC \\
$V E G F$ & GATCATGCGGATCAAACCTC & AATGCTTTCTCCGCTCTGAA \\
CD31 & ATGATGCCCAGTTGAGGTC & GACGTCTTCAGTGGGGTTGT \\
$\beta$-actin & ATCTGGCACCACACCTTC & AGCCAGGTCCAGACGCA \\
GAPDH & ATGACATCAAGAAGGTGGTG & CATACCAGGAAATGAGCTTG \\
\hline
\end{tabular}

\subsection{Flow Cytometry}

Fluorescence-activated cell sorting (FACS) analysis was used to detect cell surface markers. Cells were stained for $60 \mathrm{~min}$ at $48{ }^{\circ} \mathrm{C}$, then fixed with $2 \%$ paraformaldehyde. The surface markers investigated were FITC-conjugated mouse anti-human UEA, FITC-conjugated mouse anti-human CD31, and Alex-488-conjugated mouse anti-human c-kit (all from BD PharMingen, Franklin Lakes, NJ, USA). Isotype-identical antibodies served as negative controls. Analysis involved the use of FACS Calibur (Becton, Dickinson and Company (BD), Franklin Lakes, NJ, USA) and Cell Quest software.

\subsection{In Vitro Tube-Formation Assay}

Matrigel (300 $\mu \mathrm{L}$; Becton Dickinson, Bedford, MA, USA) was added to each well of 24-well plates. HUVECs in M199 medium and EPCs in EBM-2 medium supplemented with 20\% FBS were then plated at $1 \times 10^{5}$ cells/well and then cultured for $4 \mathrm{~h}$. After treatment with various stimuli, tube formation was examined while using an inverted microscope equipped with a digital camera. Tube-like structures exceeding six cells in length were counted in five randomly selected fields in each well by three investigators blinded to the treatment.

\subsection{Cell Migration}

HUVEC and EPC migration was assessed by scratch-wound assay, as described previously [44]. A wound was created in the cell monolayer, and images of cells were captured then and $8 \mathrm{~h}$ later. Images were quantified to determine the number of migrating cells.

\subsection{Histology Analysis and Immunofluorescence}

Formalin-fixed tissues were embedded in paraffin and sectioned $4 \mu \mathrm{m}$ thick. Hematoxylin and eosin (H\&E) staining was carried out, as described before [45]. For immunofluorescence, antigen retrieval was processed after rehydration in citrate acid buffer $\left(\mathrm{pH}\right.$ 6.0) at $95^{\circ} \mathrm{C}$ for $15 \mathrm{~min}$. Sections were blocked with 5\% BSA in PBS for $1 \mathrm{~h}$ at room temperature and then incubated overnight with anti-CD31 primary antibody diluted at 1:100 at $4{ }^{\circ} \mathrm{C}$ (Santa Cruz, Santa Cruz, CA, USA) and fluorescein iso-thiocyanate secondary antibody (Invitrogen) diluted at a 1:1000 for $2 \mathrm{~h}$ at room temperature, followed by $4{ }^{\circ} \mathrm{C}, 6$-diamidino-2-phenylindole staining for nuclei. PBS washes were performed between incubations. Sections were kept in the dark from the beginning of secondary antibody incubation and finally mounted with glycerol and immediately analyzed by fluorescent microscope (Nikon, Tokyo, Japan). 


\subsection{Statistical Analysis}

Data were expressed as means \pm SD. Data analysis used GraphPad Prism software. One-way ANOVA, Student-Newman-Keul's test (comparisons between multiple groups), or unpaired Student's $t$ test (between two groups) was used as appropriate. $p$ value $<0.05$ denotes statistical significance.

Author Contributions: J.W.: data collection, manuscript writing. L.H., B.H., L.L., H.L., J.Z.: data collection. Y.L.: project development, data collection, manuscript writing. W.Z.: manuscript writing.

Acknowledgments: This work was supported by grants from the National Natural Science Foundation of China (81670780, 81370962).

Conflicts of Interest: The authors declare no conflict of interest.

\section{References}

1. Cao, Y. Angiogenesis modulates adipogenesis and obesity. J. Clin. Investig. 2007, 117, 2362-2368. [CrossRef] [PubMed]

2. Brakenhielm, E.; Cao, R.; Gao, B.; Angelin, B.; Cannon, B.; Parini, P.; Cao, Y. Angiogenesis inhibitor, TNP-470, prevents diet-induced and genetic obesity in mice. Circ. Res. 2004, 94, 1579-1588. [CrossRef] [PubMed]

3. Lidell, M.E.; Betz, M.J.; Dahlqvist Leinhard, O.; Heglind, M.; Elander, L.; Slawik, M.; Mussack, T.; Nilsson, D.; Romu, T.; Nuutila, P.; et al. Evidence for two types of brown adipose tissue in humans. Nat. Med. 2013, 19, 631-634. [CrossRef] [PubMed]

4. Lemoine, A.Y.; Ledoux, S.; Larger, E. Adipose tissue angiogenesis in obesity. Thromb. Haemost. 2013, 110, 661-668. [CrossRef] [PubMed]

5. Crossno, J.T., Jr.; Majka, S.M.; Grazia, T.; Gill, R.G.; Klemm, D.J. Rosiglitazone promotes development of a novel adipocyte population from bone marrow-derived circulating progenitor cells. J. Clin. Investig. 2006, 116, 3220-3228. [CrossRef] [PubMed]

6. Tang, W.; Zeve, D.; Suh, J.M.; Bosnakovski, D.; Kyba, M.; Hammer, R.E.; Tallquist, M.D.; Graff, J.M. White fat progenitor cells reside in the adipose vasculature. Science 2008, 322, 583-586. [CrossRef] [PubMed]

7. Cao, Y. Angiogenesis and vascular functions in modulation of obesity, adipose metabolism, and insulin sensitivity. Cell Metab. 2013, 18, 478-489. [CrossRef] [PubMed]

8. Margaritis, M.; Antonopoulos, A.S.; Digby, J.; Lee, R.; Reilly, S.; Coutinho, P.; Shirodaria, C.; Sayeed, R.; Petrou, M.; De Silva, R.; et al. Interactions between vascular wall and perivascular adipose tissue reveal novel roles for adiponectin in the regulation of endothelial nitric oxide synthase function in human vessels. Circulation 2013, 127, 2209-2221. [CrossRef] [PubMed]

9. Folkman, J. Angiogenesis in cancer, vascular, rheumatoid and other disease. Nat. Med. 1995, 1, 27-31. [CrossRef] [PubMed]

10. Lijnen, H.R. Angiogenesis and obesity. Cardiovasc. Res. 2008, 78, 286-293. [CrossRef] [PubMed]

11. Cooke, D.; Bloom, S. The obesity pipeline: Current strategies in the development of anti-obesity drugs. Nat. Rev. Drug Discov. 2006, 5, 919-931. [CrossRef] [PubMed]

12. Elgart, J.F.; Prestes, M.; Gonzalez, L.; Rucci, E.; Gagliardino, J.J.; QUALIDIAB Net Study Group. Relation between cost of drug treatment and body mass index in people with type 2 diabetes in Latin America. PLoS ONE 2017, 12, e0189755. [CrossRef] [PubMed]

13. Kojima, M.; Hosoda, H.; Date, Y.; Nakazato, M.; Matsuo, H.; Kangawa, K. Ghrelin is a growth-hormone-releasing acylated peptide from stomach. Nature 1999, 402, 656-660. [CrossRef] [PubMed]

14. Gnanapavan, S.; Kola, B.; Bustin, S.A.; Morris, D.G.; McGee, P.; Fairclough, P.; Bhattacharya, S.; Carpenter, R.; Grossman, A.B.; Korbonits, M. The tissue distribution of the mRNA of ghrelin and subtypes of its receptor, GHS-R, in humans. J. Clin. Endocrinol. Metab. 2002, 87, 2988. [CrossRef] [PubMed]

15. Gariano, R.F.; Gardner, T.W. Retinal angiogenesis in development and disease. Nature 2005, 438, 960-966. [CrossRef] [PubMed]

16. Li, A.; Cheng, G.; Zhu, G.H.; Tarnawski, A.S. Ghrelin stimulates angiogenesis in human microvascular endothelial cells: Implications beyond GH release. Biochem. Biophys. Res. Commun. 2007, 353, 238-243. [CrossRef] [PubMed] 
17. Katare, R.; Rawal, S.; Munasinghe, P.E.; Tsuchimochi, H.; Inagaki, T.; Fujii, Y.; Dixit, P.; Umetani, K.; Kangawa, K.; Shirai, M.; et al. Ghrelin Promotes Functional Angiogenesis in a Mouse Model of Critical Limb Ischemia through Activation of Proangiogenic MicroRNAs. Endocrinology 2016, 157, 432-445. [CrossRef] [PubMed]

18. Liu, B.; Garcia, E.A.; Korbonits, M. Genetic studies on the ghrelin, growth hormone secretagogue receptor (GHSR) and ghrelin O-acyl transferase (GOAT) genes. Peptides 2011, 32, 2191-2207. [CrossRef] [PubMed]

19. Sun, Y.; Liu, W.Z.; Liu, T.; Feng, X.; Yang, N.; Zhou, H.F. Signaling pathway of MAPK/ERK in cell proliferation, differentiation, migration, senescence and apoptosis. J. Recep. Signal Transduct. Res. 2015, 35, 600-604. [CrossRef] [PubMed]

20. Depoortere, I.; Thijs, T.; Peeters, T. The contractile effect of the ghrelin receptor antagonist, D-Lys3-GHRP-6, in rat fundic strips is mediated through 5-HT receptors. Eur. J. Pharmacol. 2006, 537, 160-165. [CrossRef] [PubMed]

21. Nishimoto, S.; Nishida, E. MAPK signalling: ERK5 versus ERK1/2. EMBO Rep. 2006, 7, 782-786. [CrossRef] [PubMed]

22. Perchard, R.; Clayton, P.E. Ghrelin and Growth. Endocr. Dev. 2017, 32, 74-86. [PubMed]

23. Li, Z.; Xu, G.; Qin, Y.; Zhang, C.; Tang, H.; Yin, Y.; Xiang, X.; Li, Y.; Zhao, J.; Mulholland, M.; et al. Ghrelin promotes hepatic lipogenesis by activation of mTOR-PPARgamma signaling pathway. Proc. Natl. Acad. Sci. USA 2014, 111, 13163-13168. [CrossRef] [PubMed]

24. Zhang, W.; Lin, T.R.; Hu, Y.; Fan, Y.; Zhao, L.; Stuenkel, E.L.; Mulholland, M.W. Ghrelin stimulates neurogenesis in the dorsal motor nucleus of the vagus. J. Physiol. 2004, 559 Pt 3, 729-737. [CrossRef]

25. Elias, I.; Franckhauser, S.; Ferre, T.; Vila, L.; Tafuro, S.; Munoz, S.; Roca, C.; Ramos, D.; Pujol, A.; Riu, E.; et al. Adipose tissue overexpression of vascular endothelial growth factor protects against diet-induced obesity and insulin resistance. Diabetes 2012, 61, 1801-1813. [CrossRef] [PubMed]

26. Sawane, M.; Kajiya, K.; Kidoya, H.; Takagi, M.; Muramatsu, F.; Takakura, N. Apelin inhibits diet-induced obesity by enhancing lymphatic and blood vessel integrity. Diabetes 2013, 62, 1970-1980. [CrossRef] [PubMed]

27. Carmeliet, P.; Jain, R.K. Molecular mechanisms and clinical applications of angiogenesis. Nature 2011, 473, 298-307. [CrossRef] [PubMed]

28. Sim, B.K. Angiostatin and endostatin: Endothelial cell-specific endogenous inhibitors of angiogenesis and tumor growth. Angiogenesis 1998, 2, 37-48. [CrossRef] [PubMed]

29. Bruemmer, D. Targeting angiogenesis as treatment for obesity. Arterioscler. Thromb. Vasc. Biol. 2012, 32, 161-162. [CrossRef] [PubMed]

30. Lu, X.; Ji, Y.; Zhang, L.; Zhang, Y.; Zhang, S.; An, Y.; Liu, P.; Zheng, Y. Resistance to obesity by repression of VEGF gene expression through induction of brown-like adipocyte differentiation. Endocrinology 2012, 153, 3123-3132. [CrossRef] [PubMed]

31. Rupnick, M.A.; Panigrahy, D.; Zhang, C.Y.; Dallabrida, S.M.; Lowell, B.B.; Langer, R.; Folkman, M.J. Adipose tissue mass can be regulated through the vasculature. Proc. Natl. Acad. Sci. USA 2002, 99, 10730-10735. [CrossRef] [PubMed]

32. Kim, Y.M.; An, J.J.; Jin, Y.J.; Rhee, Y.; Cha, B.S.; Lee, H.C.; Lim, S.K. Assessment of the anti-obesity effects of the TNP-470 analog, CKD-732. J. Mol. Endocrinol. 2007, 38, 455-465. [CrossRef] [PubMed]

33. White, H.M.; Acton, A.J.; Considine, R.V. The angiogenic inhibitor TNP-470 decreases caloric intake and weight gain in high-fat fed mice. Obesity (Silver Spring) 2012, 20, 2003-2009. [CrossRef] [PubMed]

34. Sun, K.; Wernstedt Asterholm, I.; Kusminski, C.M.; Bueno, A.C.; Wang, Z.V.; Pollard, J.W.; Brekken, R.A.; Scherer, P.E. Dichotomous effects of VEGF-A on adipose tissue dysfunction. Proc. Natl. Acad. Sci. USA 2012, 109, 5874-5879. [CrossRef] [PubMed]

35. Sung, H.K.; Doh, K.O.; Son, J.E.; Park, J.G.; Bae, Y.; Choi, S.; Nelson, S.M.; Cowling, R.; Nagy, K.; Michael, I.P.; et al. Adipose vascular endothelial growth factor regulates metabolic homeostasis through angiogenesis. Cell Metab. 2013, 17, 61-72. [CrossRef] [PubMed]

36. Nedergaard, J.; Bengtsson, T.; Cannon, B. Unexpected evidence for active brown adipose tissue in adult humans. Am. J. Physiol. Endocrinol. Metab. 2007, 293, E444-E452. [CrossRef] [PubMed]

37. Tran, K.V.; Gealekman, O.; Frontini, A.; Zingaretti, M.C.; Morroni, M.; Giordano, A.; Smorlesi, A.; Perugini, J.; De Matteis, R.; Sbarbati, A.; et al. The vascular endothelium of the adipose tissue gives rise to both white and brown fat cells. Cell Metab. 2012, 15, 222-229. [CrossRef] [PubMed] 
38. Wu, J.; Bostrom, P.; Sparks, L.M.; Ye, L.; Choi, J.H.; Giang, A.H.; Khandekar, M.; Virtanen, K.A.; Nuutila, P.; Schaart, G.; et al. Beige adipocytes are a distinct type of thermogenic fat cell in mouse and human. Cell 2012, 150, 366-376. [CrossRef] [PubMed]

39. Zigman, J.M.; Nakano, Y.; Coppari, R.; Balthasar, N.; Marcus, J.N.; Lee, C.E.; Jones, J.E.; Deysher, A.E.; Waxman, A.R.; White, R.D.; et al. Mice lacking ghrelin receptors resist the development of diet-induced obesity. J. Clin. Investig. 2005, 115, 3564-3572. [CrossRef] [PubMed]

40. Wang, L.; Chen, Q.; Li, G.; Ke, D. Ghrelin stimulates angiogenesis via GHSR1a-dependent MEK/ERK and $\mathrm{PI} 3 \mathrm{~K} /$ Akt signal pathways in rat cardiac microvascular endothelial cells. Peptides 2012, 33, 92-100. [CrossRef] [PubMed]

41. Xu, G.; Wang, Z.; Li, Y.; Li, Z.; Tang, H.; Zhao, J.; Xiang, X.; Ding, L.; Ma, L.; Yuan, F.; et al. Ghrelin contributes to derangements of glucose metabolism induced by rapamycin in mice. Diabetologia 2012, 55, 1813-1823. [CrossRef] [PubMed]

42. Sekiguchi, H.; Ii, M.; Jujo, K.; Yokoyama, A.; Hagiwara, N.; Asahara, T. Improved culture-based isolation of differentiating endothelial progenitor cells from mouse bone marrow mononuclear cells. PLoS ONE 2011, 6, e28639. [CrossRef] [PubMed]

43. Zhu, Z.; Fu, C.; Li, X.; Song, Y.; Li, C.; Zou, M.; Guan, Y.; Zhu, Y. Prostaglandin E2 promotes endothelial differentiation from bone marrow-derived cells through AMPK activation. PLoS ONE 2011, 6, e23554. [CrossRef] [PubMed]

44. Song, Y.; Li, X.; Wang, D.; Fu, C.; Zhu, Z.; Zou, M.H.; Zhu, Y. Transcription factor Kruppel-like factor 2 plays a vital role in endothelial colony forming cells differentiation. Cardiovasc. Res. 2013, 99, 514-524. [CrossRef] [PubMed]

45. Mulder, P.; Morrison, M.C.; Verschuren, L.; Liang, W.; van Bockel, J.H.; Kooistra, T.; Wielinga, P.Y.; Kleemann, R. Reduction of obesity-associated white adipose tissue inflammation by rosiglitazone is associated with reduced non-alcoholic fatty liver disease in LDLr-deficient mice. Sci. Rep. 2016, 6, 31542. [CrossRef] [PubMed]

(C) 2018 by the authors. Licensee MDPI, Basel, Switzerland. This article is an open access article distributed under the terms and conditions of the Creative Commons Attribution (CC BY) license (http:/ / creativecommons.org/licenses/by/4.0/). 